\title{
Phytoprotection
}

\section{Effecs of damage by wheat bug, Aelia germari [Hemiptera : Pentatomidae], on grain quality and on reproductive performance of the rice weevil, Sitophilus oryzae [Coleoptera : curculionidae]}

\author{
R. Fourar et F. Fleurat-Lessard
}

Volume 78, numéro 3, 1997

URI : https://id.erudit.org/iderudit/706125ar

DOI : https://doi.org/10.7202/706125ar

Aller au sommaire du numéro

Éditeur(s)

Société de protection des plantes du Québec (SPPQ)l

ISSN

0031-9511 (imprimé)

1710-1603 (numérique)

Découvrir la revue

Citer cet article

Fourar, R. \& Fleurat-Lessard, F. (1997). Effecs of damage by wheat bug, Aelia germari [Hemiptera : Pentatomidae], on grain quality and on reproductive performance of the rice weevil, Sitophilus oryzae [Coleoptera : curculionidae]. Phytoprotection, 78(3), 105-116. https://doi.org/10.7202/706125ar
Résumé de l'article

La punaise des céréales, Aelia germari, cause des dégâts au champ, avant la maturité du grain, qui ont pour conséquence majeure une réduction de la valeur boulangère du blé destiné à la panification. Pour tenter de mettre en évidence les modifications induites par les attaques de punaises sur la valeur nutritive du grain, un essai biologique a été réalisé sur le charançon du riz Sitophilus oryzae, qui se développe dans l'endosperme du grain. Le charançon du riz a été élevé sur des échantillons de blé du cultivar 'Manondemias', dans lesquels ont été incorporés des taux différents $(0,4,8$, et $13 \%)$ de grain attaqué par la punaise phytophage $A$. germari. Sur les échantillons de blé punaisé à 4,8 ou $13 \%$, la durée moyenne de développement de $S$. oryzae était plus courte que sur le grain non punaisé. Cependant, le calcul des corrélations sur les variables prises deux à deux a montré que ni l'indice de sensibilité Dobie aux attaques d'insectes, ni la descendance par femelle de charançon, ni la perte de poids du grain consécutive au développement complet de $S$. oryzae, n'étaient corrélés avec le pourcentage de grains punaisés dans l'échantillon. À partir d'une analyse multivariable globale, associant les propriétés physicochimiques ou rhéologiques des grains avec les paramètres décrivant la réponse biologique du charançon $S$. oryzae, il a été montré que le blé sans attaque apparente de punaise pouvait être associé à une longue durée de développement pour $S$. oryzae, un nombre plus faible de descendants, une force boulangère, une teneur en azote et un temps de chute élevés, ainsi qu'à une faible teneur en cendres et en azote assimilable du grain. 


\title{
Effects of damage by wheat bug, Aelia germari [Hemiptera: Pentatomidae], on grain quality and on reproductive performance of the rice weevil, Sitophilus oryzae [Coleoptera : Curculionidae], on harvested grain
}

\author{
Rebiha Fourar ${ }^{1}$ and Francis Fleurat-Lessard ${ }^{2}$
}

Received 1997-04-02; accepted 1997-07-18

PHYTOPROTECTION 78 : 105-116

The wheat bug, Aelia germari, feeds on developing wheat kernels, causing a loss in baking quality of the harvested wheat (Triticum aestivum). The possible nutritional changes in the bug-damaged kernels after the harvest were tested in a bioassay using the rice weevil Sitophilus oryzae, which feeds on the kernel endosperm. The weevils were reared on baking wheat cultivar 'Mahon demias', grown in Algeria, with different levels (0, 4, 8 and $13 \%$ ) of wheat bug ( $A$. germari) damaged kernels. Rice weevil reared on 4,8 or $13 \%$ damaged wheat had a shorter development time than on wheat with no damage. However, pair-wise correlations showed that Dobie's index for susceptibility of grain for stored-products insect attack, number of progeny per female and kernel weight loss were not correlated with the percentage of damaged kernels. Using multivariate analysis, the general characteristics of high quality grain were associated with long development times for $S$. oryzae, low number of progeny, high baking strength, high falling number, high nitrogen, low ash content, and low assimilable nitrogen.

[Influence des attaques en culture de la punaise des céréales, Aelia germari [Hemiptera : Pentatomidae], sur la valeur nutritive du blé et le développement du charançon du riz, Sitophilus oryzae [Coleoptera : Curculionidae], après la récolte]

La punaise des céréales, Aelia germari, cause des dégâts au champ, avant la maturité du grain, qui ont pour conséquence majeure une réduction de la valeur boulangère du blé destiné à la panification. Pour tenter de mettre en évidence les modifications induites par les attaques de punaises sur la valeur nutritive du grain, un essai biologique a été réalisé sur le charançon du riz Sitophilus oryzae, qui se développe dans l'endosperme du grain. Le charançon du riz a été élevé sur des échantillons de blé du cultivar 'Mahon demias', dans lesquels ont été incorporés des taux différents $(0,4$, 8 , et $13 \%$ ) de grain attaqué par la punaise phytophage $A$. germari. Sur les

1. Centre de Recherche en Industries Agro-Alimentaires, ENIAL, 6, chemin Javal, 09000 Blida, Algérie

2. INRA, Laboratoire des Insectes des Denrées, B.P. 81, 33883 Villenave d'Ornon cedex, France 
échantillons de blé punaisé à 4, 8 ou 13\%, la durée moyenne de développement de $S$. oryzae était plus courte que sur le grain non punaisé. Cependant, le calcul des corrélations sur les variables prises deux à deux a montré que ni l'indice de sensibilité Dobie aux attaques d'insectes, ni la descendance par femelle de charançon, ni la perte de poids du grain consécutive au développement complet de $S$. oryzae, n'étaient corrélés avec le pourcentage de grains punaisés dans l'échantillon. À partir d'une analyse multivariable globale, associant les propriétés physico-chimiques ou rhéologiques des grains avec les paramètres décrivant la réponse biologique du charançon $S$. oryzae, il a été montré que le blé sans attaque apparente de punaise pouvait être associé à une longue durée de développement pour $S$. oryzae, un nombre plus faible de descendants, une force boulangère, une teneur en azote et un temps de chute élevés, ainsi qu'à une faible teneur en cendres et en azote assimilable du grain.

\section{INTRODUCTION}

Aelia germari Kuster [Hemiptera : Pentatomidae] is the most damaging wheat bug pest in Algeria, and is a problem in all southern Mediterranean areas where wheat (Triticum aestivum L.) is grown. Wheat bugs also cause important damage to wheat in New Zealand (Swallow and Every 1991). Like the migratory grasshopper (Locusta migratoria L.), A. germari is a strong flier and infestations can spread rapidly, causing widespread damage in Algerian wheat fields (Gaffour-Bensebbane 1979). This pentatomid feeds on developing wheat kernels by inserting its stylet into the kernel, injecting enzymes and sucking up the extra-oral digested material. Damaged kernels can be detected as feeding causes a black speck surrounded by a whitened circle.

Although damaged kernels are about the same size as sound ones, the damaged kernels have less dry matter and more importantly, greatly reduce bread baking quality (Dubois and Validzic 1952; Gaffour-Bensebbane 1979; Menadi 1989; Mzali 1977; Swallow and Every 1991; Zoubovsky 1955). Wheat varieties with a high baking strength index (W) can still produce usable flour even with $1 \%$ wheat bug damaged kernels (Zoubovsky 1955). However, wheat varieties with a medium $W$ become unusable for bread making at the same level of attack. There are numerous variables that determine the effect of wheat bug feeding on baking quality: the pest species, the number of punctures per kernel and the initial baking quality of the wheat flour (W, elasticity and stickiness of flour dough). Consequently, simply using the rate of bugdamaged grain is not a good predictor of baking quality. The effects of the bug attack may be more exactly assessed by biochemical and technological tests. Currently, we do not have a rapid chemical test that will accurately predict bread making quality in harvested wheat. In addition, the prediction of baking quality with technological tests or rheological test remains difficult, or impossible when there is only a small quantity of wheat available.

Primary insect pests living inside grain after the harvest, such as the cosmopolitan species Sitophilus oryzae (L.) [Coleoptera : Curculionidae], are known to be sensitive to slight changes in nutritional value of kernel endosperm for different cereals (Davis and Sosulski 1976; Leclercq and de Bast 1965; Loschiavo et al. 1969). Sitophilus oryzae may be a discriminant species to test the susceptibility of bug-damaged kernels to stored-grain insects and to characterize the global changes in nutritional quality of the grain endosperm that occur after wheat bug feeding. The present investigation was undertaken to determine the relationship between the level of damage caused by the wheat bug to the kernels and biological response of the rice weevil on bug-dam- 
aged grain and to correlate these results with traditional assessment of the extent of bug damage by rheological and analytical measurements on the extracted flour.

\section{MATERIALS AND METHODS}

\section{Biochemical and technological analyses on wheat}

The changes in biochemical composition of grain and in technological properties caused by the wheat bug damage were assessed using mainly standard methods. The germination capacity was measured on four replicates of 100 seeds at $20^{\circ} \mathrm{C}$ on wet filter paper following an ISTA (International Seed Testing Association) standard procedure (1976). The weight per $\mathrm{hL}$ of grain, usually used to assess the bulk density, was evaluated by using Algerian Standard for cereal grain NA - 1 613-90, weighing $1 \mathrm{~L}$ of grain in standard conditions. The determination of the weight of 1000 kernels followed Algerian standard NA - 7-31-90, in agreement with French Standard NF V 03-702. The calibration of the size of kernels was performed on two 1000-kernel grain samples, one originating from harvest with a $4 \%$ bug damage level and the other constituted from $100 \%$ externally-visible damaged kernels selected out from the $4 \%$ bugdamaged initial grain batch. Each grain sample was separated into three classes of size: \% large kernels, size $>2.9 \mathrm{~mm}$; $\%$ medium size kernels, size $<2.9$ and $>2.3 \mathrm{~mm}$; \% small size kernels, size $<2.3 \mathrm{~mm}$ (no replication, each 1000kernel sample was sieved). The grain hardness was assessed on a 100-kernel sample by a "hardness tester", Pharmatest $\AA$ PTB 311, which determined the resistance to penetration into the kernel of a needle, converted into power applied for penetration in Newton units. The percentage of ash was obtained by using French standard NF V 03-760, which involves burning $5 \mathrm{~g}$ of grain in a special oven at $550^{\circ} \mathrm{C}$. The protein content was derived from nitrogen content analysis using the Kjeldahl standard method (French Standard NF V 03$050 ; N \% \times 5.7)$. The percentage of degradable nitrogen (or assimilable nitrogen) was obtained using the Aufrere method (Aufrere and MichaletDoreau 1988). This method is used to predict the percentage of assimilable nitrogen in feed products through enzymatic digestion of the sample.

The bread making quality was assessed by the falling number test (Hagberg index) measuring the changes in $\alpha$-amylase activity that relates to the starch paste viscosity (Algerian Standard NA 1176-90 = NF V 03-703), and alveographic analysis for the estimation of baking strength index (W) and rheological characteristics of the bread dough $(P / L$ ratio with tenacity $P$ and extensibility $L$, and $G$ index relative to its inflation capacity) using Algerian Standard NA 1188-90, consistent with French Standard NF V 03-710 (Alvéographe Chopin (®). The alveographic test needed to be modified to obtain a normal alveographic curve with bugdamaged wheat cv. 'Mahon demias', since this variety has a poor natural baking strength index. We mixed $5 \%$ of the bug-damaged grain $10,4,8$, and $13 \%$ damaged kernels) with sound grain of a standard variety of wheat with a good bread-making quality. Thus, the final $\%$ bug-damaged wheat in the samples was respectively $0,0.2,0.4$, and $0.65 \%$. The resting time of the dough before alveographic analysis was increased to $3 \mathrm{~h}$ instead of the standard $20 \mathrm{~min}$. The "virulence index" (V) of bug attack, describing the alteration of rheological properties of bread dough, was calculated from results obtained with this modified method:

$$
V=\frac{W c-W b}{W c} \times 100
$$

where:

$$
\begin{aligned}
\mathrm{V}= & \text { virulence of bug attack }(\%) \\
\mathrm{Wc}= & \text { baking strength index } \mathrm{W} \text { of } \\
& \begin{array}{l}
\text { control (sound) wheat }\left(10^{-4} \mathrm{~J} \mathrm{~g}^{-1}\right. \\
\text { of dough) }
\end{array} \\
\mathrm{Wb}= & \text { baking strength index } \mathrm{W} \text { of } \\
& \begin{array}{l}
\text { wheat with bug-damaged ker- } \\
\text { nels }\left(10^{-4} \mathrm{~J} \mathrm{~g}^{-1}\right. \text { of dough) }
\end{array}
\end{aligned}
$$




\section{Bioassay with insects}

The initial batch of wheat cultivar 'Mahon demias' was harvested with a $4 \%$ level of wheat bug-damaged kernels, and it was stored free of insecticide treatment before the experiments. From this grain, damaged kernels were selected out to make up a sample of $100 \%$ damaged kernels, which was diluted with sound wheat to give additional samples with $13,8,4$, and $0 \%$ damaged kernels. A $13 \%$ damage level was chosen because it is the legal limit for foodgrade wheat in Algeria. Sitophilus oryzae was chosen for the bioassay because it has a short life cycle, is a common pest of stored grain in regions where the wheat bug is also a pest and the larvae feed internally on the grain endosperm. We used a French strain of this species that has been reared for 20 $\mathrm{yr}$ in laboratory conditions at $25^{\circ} \mathrm{C}, 70 \%$ relative humidity $(\mathrm{RH})$ on whole wheat grain. Five pairs of $S$. oryzae adults were chosen during the first mating after emergence from the kernel (4-7 d old), and placed on $50 \mathrm{~g}$ of wheat at $25 \pm 1^{\circ} \mathrm{C}$, $70 \pm 10 \% \mathrm{RH}$. The grain was held at these conditions $1 \mathrm{wk}$ before infestation with the weevils to allow for moisture content equilibrium. The adults were removed after a 12-d oviposition period. Four wk after adults were placed on the grain samples, emerging adults (first generation progeny) were counted and removed daily. The progeny emergence was considered finished when there were five consecutive days without any weevil emergence. Each bioassay had five replicates.

\section{Biological indexes}

The median developmental time (MDT) was obtained by a simple calculation of the time lasting between the median day of the oviposition period (6 d after introduction of the weevils on the grain sample) and the time when $50 \%$ of the weevil population has emerged (Bekon and Fleurat-Lessard 1988; Haryadi 1991).

$$
M D T=D x+\frac{n_{50}-n_{x}}{n_{y}-n_{x}} x(D y-D x)
$$

where :

MDT $=$ median developmental time (d)

$D x=$ the last day before $50 \%$ emergence of the weevil population occurs (d)

Dy $=$ the first day after the time of $50 \%$ emergence (d)

$\mathrm{n}_{\mathrm{x}}=$ cumulative number of weevils emerged at Dx

$\mathrm{n}_{\mathrm{y}}=$ cumulative number of weevils emerged at Dy

$n_{50}=50 \%$ of the total number of emerged weevils at the end of assay

Dobie's index of susceptibility for insect attack of grain (Dobie 1974) can be calculated using MDT from above and the mean number of progeny per female (F) :

Dobie's Index (DI) $=100\left\{\ln \left(\mathrm{F} \mathrm{MDT}^{-1}\right)\right\}$

In the current study, we used a simplified calculation in including directly into Dobie's formula the mean progeny of five females instead of the mean number of progeny per female. Weight losses caused by the development of one generation of $S$. oryzae were assessed by using the 1000-kernel weight measurement (Adams and Schulten 1978).

\section{Statistical analysis}

Variation in single criteria and variables was assessed by an ANOVA with oneway analysis and the means were compared using Newman-Keuls test. (with significance established at $P \leq 0.05$ ). When correlation between variables was suspected, simple correlations were calculated and the global influence of bug attack on the wheat flour quality for the weevils was estimated from a full combination of influent variables into a principal component analysis. This illustrated the interrelations of all criteria and parameters involved in, or affected by bug attack of wheat grain. All the statistical analyses were performed with STAT-ITCF software (ITCF 1988). 


\section{RESULTS AND DISCUSSION}

\section{Effect of wheat bug feeding on baking quality}

The increased levels of bug attack on wheat caused a significant reduction in 1000-kernel weight $(r=0.998 ; P=0.04$; Table 1). The distributions of kernel size classes established for $100 \%$ bugdamaged kernels and sound ones were significantly different $\left(\chi^{2}=5.26 ; P=\right.$ $0.024)$. This reduction in the size of a bug-damaged kernel was confirmed by the radiographic picture of damaged grain compared to sound grain (Fig. 1) where we detected that the bug puncture induces a hole in the wheat kernel and a malformation that often reduces its length. The amplitude of these modifications could depend on the degree of ripening when the bug fed on the kernel. The mean hardness of grain was greatly reduced in damaged kernels, in relation to the increased brittleness of the part of the grain where bug saliva has been injected. The difference in the density of internal structure of the kernel endosperm was visible on the radiographs (Fig. 1). Bug-damaged kernels had lower rates of germination (Table 1). This type of damage is of particular importance for wheat which is grown for seed production. The ash content of grain increased directly with the degree of kernel damage (Table 2). It may be that the percentage of external layers of the grain (especially bran layers) remains unchanged after insect puncture, whereas endosperm proportion decreases in the attacked grain. The ratio of outer layers, which contain up to $67 \%$ of mineral matter (Hinton 1959), to internal endosperm increased and so did the ash content. Although the nitrogen content was not significantly modified, the percentage of degradable nitrogen increased regularly with the level of damaged grain. This may be caused by the injection of proteolytic enzymes by the wheat bug into the kernel, which causes extra-oral protein degradation, and the bug being not able to remove all the digested endosperm. We concluded that this increase in digestibility was mainly related to the gluten fraction of albumen, as there was only a small reduction in falling number index, indicating no significant changes in the properties of

Table 1. Effect of wheat bug attack on technological properties of wheat graina cv. 'Mahon demias', with 4 or $100 \%$ damaged kernels compared to sound kernels

Analytical results

Bug-damaged kernels (\%)

\begin{tabular}{|c|c|c|c|}
\hline & 0 & 4 & 100 \\
\hline Moisture content (\% dm) & 10.4 & 10.9 & - $^{\mathrm{b}}$ \\
\hline Bulk density $\left(\mathrm{kg} \mathrm{hL}^{-1}\right)$ & 78 & 77 & - \\
\hline Dry weight of 1000 kernels $(\mathrm{g})$ & 30.4 & 29.8 & 24.8 \\
\hline$>2.8 \mathrm{~mm}$ & 42.2 & - & $38.6^{* c}$ \\
\hline$<2.8$ and $>2.3 \mathrm{~mm}$ & 23.1 & - & $24.6^{*}$ \\
\hline$<2.3 \mathrm{~mm}$ & 34.7 & - & $36.8^{*}$ \\
\hline Hardness (N) & 77.7 & - & 66.8 \\
\hline Germination capacity ${ }^{d}$ & 100 & $98 * e$ & $87^{* f}$ \\
\hline Protein content ( $\% \mathrm{dm})$ & 17.3 & 16.9 & - \\
\hline Zeleny index $(\mathrm{mL})$ & 29 & 24 & - \\
\hline Falling number (= Hagberg index) (s) & 422 & 428 & - \\
\hline Fat acidity $\left(\mathrm{H}_{2} \mathrm{SO}_{4}, \% \mathrm{dm}\right)$ & 0.037 & 0.032 & - \\
\hline
\end{tabular}

a Data concerning the grain batch taken directly in the field.

b Missing value because of the lack of the minimum quantity required or unable to take the measurement.

c Distribution in each size class significantly different $(P=0.024)$ according to $\chi^{2}$ test.

d Average of four replicates.

e Confidence limits $95 \%: 93.0$ to 99.8 .

f Abnormal germination (confidence limits $95 \%: 78.8$ to 92.9 ). 

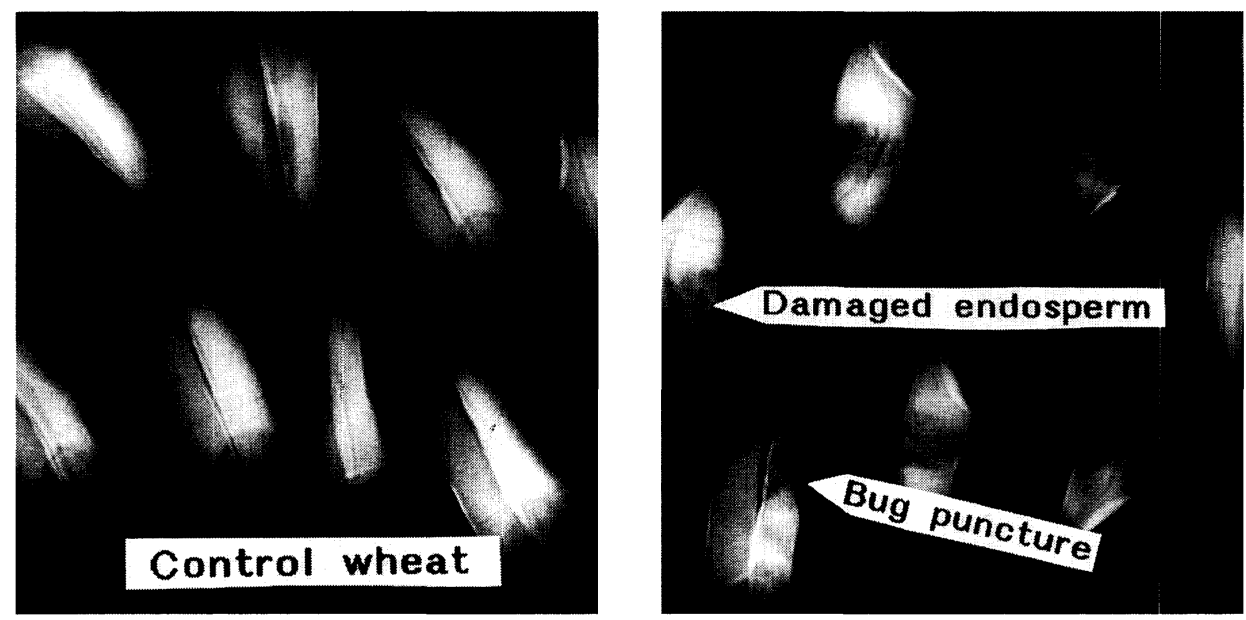

Figure 1. X-rays picture of sound wheat grain (left) compared to bug-damaged grain (right). The part of the kernel endosperm damaged by the bug puncture has a different density to $X$ rays and appears darker on the radiograph picture.

starch. Nevertheless, the progressive reduction in falling number index was correlated to the natural logarithm of the level of bug damage (Table 2).

The most important effect was observed on baking strength index, $W$, as measured by the virulence index. The virulence index increased as the percent of bug-damaged kernels increased
(Table 2). The baking quality of flour extracted from sound grain (cv. Mahon demias), free of an observable bug puncture, was acceptable with a virulence index of less than $20 \%$, the maximum level tolerated by baking industry. Above this level of $4 \%$ damaged kernels, the indexes related to breadmaking quality deteriorated beyond the acceptable technological limit (Table 3).

Table 2. Analytical characteristics of wheat grain cv. 'Mahon demias' at different levels of damage by the wheat bug and linear regression between the percentage of damaged kernels and each characteristic

\begin{tabular}{cccccccc}
\hline $\begin{array}{c}\text { Damaged } \\
\text { kernels } \\
(\%)\end{array}$ & $\begin{array}{c}\text { Moisture } \\
\text { content } \\
(\% \text { wb })^{\mathrm{a}}\end{array}$ & $\begin{array}{c}\text { Mineral } \\
\text { ash } \\
(\% \mathrm{dm})\end{array}$ & $\begin{array}{c}\text { Nitrogen } \\
\text { content } \\
(\% \mathrm{dm})\end{array}$ & $\begin{array}{c}\text { Degradable } \\
\text { nitrogen } \\
(\%)\end{array}$ & $\begin{array}{c}\text { Hardness } \\
\text { index } \\
(\mathrm{N})^{\mathrm{b}}\end{array}$ & $\begin{array}{c}\text { Falling } \\
\text { number } \\
(\mathrm{S})^{\mathrm{c}}\end{array}$ & $\begin{array}{c}\text { Virulence } \\
\text { index } \\
(\%)\end{array}$ \\
\hline 0 & 13.3 & 2.23 & 3.1 & 13 & 77.6 & $391 \pm 17$ & 3.3 \\
4 & 13.4 & 2.32 & 3.1 & 13 & - & $378 \pm 14$ & 20 \\
8 & 13.4 & 2.45 & 3 & 15 & - & $368 \pm 3$ & 46.7 \\
13 & 13.2 & 2.78 & 2.9 & 15 & - & $375 \pm 10$ & 60 \\
100 & - & - & 3 & 21 & 66.8 & $365 \pm 5$ & - \\
$r$ & -0.13 & 0.97 & 0.10 & 0.98 & - & $-0.87^{\mathrm{d}}$ & 0.99 \\
$P$ & 0.43 & 0.03 & 0.87 & 0.003 & - & 0.05 & 0.01 \\
slope & $\mathrm{nc}$ & 0.04 & $\mathrm{nc}$ & 0.076 & - & -5.29 & 4.54 \\
intercept & $\mathrm{nc}$ & 2.18 & $\mathrm{nc}$ & 13.5 & - & 386 & 4.12 \\
\hline
\end{tabular}

a Wet basis.

b Newton unit.

c \pm Standard deviation.

d Regression with natural logarithm (In) transformation for abcissa (\% bug damage).

- Missing value because of the lack of the minimum quantity required, or unable to measure.

nc Not calculated. 
Table 3. Degradation of bread making properties of flour made from wheat damaged by wheat bug attack at different levels of damage. Determination of uvirulence" (V) for breadmaking strength (W) of wheat flour

Alveographic characteristics ${ }^{b}$

\begin{tabular}{|c|c|c|c|c|c|c|c|c|c|}
\hline \multirow[b]{2}{*}{$\begin{array}{l}\text { Proportion of bug- } \\
\text { damaged grain }\end{array}$} & \multicolumn{4}{|c|}{ Standard protocol } & \multicolumn{4}{|c|}{$\begin{array}{l}\text { Modified method ( } 3 \mathrm{~h} \\
\text { resting time of dough) }\end{array}$} & \multirow[b]{2}{*}{$\begin{array}{l}\text { Virulence } \\
\text { index }(\%)\end{array}$} \\
\hline & $\begin{array}{c}\text { W } \\
\left(\operatorname{erg~g}^{-1}\right)\end{array}$ & $\underset{(\mathrm{mm})}{\mathrm{P}}$ & $\underset{(m L)}{G}$ & $P / L$ & $\begin{array}{c}\text { W } \\
\left(\operatorname{erg~g}^{-1}\right)\end{array}$ & $\underset{(\mathrm{mm})}{\mathrm{P}}$ & $\underset{(m L)}{G}$ & $P / L$ & \\
\hline MD $100 \%$ sound (MD-0) & 45 & 44.5 & 13.3 & 1.27 & \multicolumn{4}{|c|}{ Incalculable } & \\
\hline MD $4 \%$ damaged (MD-4) & & Incalc & ulable & & - & - & - & - & - \\
\hline Control Wheat (CW) & - & - & - & - & 150 & 66.1 & 17.2 & 1.1 & 0 \\
\hline $\mathrm{CW}+5 \%(\mathrm{MD}-0)$ & - & - & - & - & 145 & 63.2 & 17.2 & 1.05 & 3.3 \\
\hline $\mathrm{CW}+5 \%(\mathrm{MD}-4)$ & - & - & - & - & 120 & 53.9 & 17.4 & 0.87 & 20 \\
\hline$C W+5 \%(M D-8)$ & - & - & - & - & 80 & 53.9 & 13.3 & 1.5 & 46.7 \\
\hline$C W+5 \%(M D-13)$ & - & - & - & - & 60 & 44.8 & 13.4 & 1.23 & 60 \\
\hline
\end{tabular}

a $\mathrm{MD}=$ Wheat cultivar 'Mahon demias'; $\mathrm{CW}=$ control wheat for alveographic tests ; example : (MD-8) = MD with $8 \%$ bug-damaged kernels.

b Alveographic coefficients: $W=$ baking strength index $; P=$ elasticity coefficient $; G=$ inflation capacity $; \mathrm{P} / \mathrm{L}=$ meaningful ratio for bread-making dough.

Flour derived from $8 \%$ bug-damaged wheat had rheological properties so modified that it could not be used for bread making, with a virulence index of more than $40 \%$. This threshold is in good agreement with one of the first studies on this topic (Kosmin 1933).

\section{Effect of wheat bug damage on S. oryzae development}

The mean progeny per female weevil was not affected by the level of bugdamaged grain with 26 to 27 progeny per parent weevil (Table 4). However, there was a decrease in the median developmental time (MDT) with the increase in the percentage of bug-damaged grain in the samples $(P=0.013)$. In $100 \%$ damaged kernels, MDT was reduced by about 3\% compared to sound kernel controls (Table 4). For the other levels $(4,8$ and $13 \%)$ of bugdamaged grain, the MDT was not different than for sound grain. Consequently, the modified Dobie's index, which involves MDT, did not change

Table 4. Progeny of 5 females, Median Developmental Time, modified Dobie's index of grain susceptibility to insects, and percentage of loss induced by a generation of $S$. oryzae reared on wheat, damaged by the wheat bug at different levels

\begin{tabular}{|c|c|c|c|c|}
\hline $\begin{array}{c}\text { Bug } \\
\text { damage }(\%)\end{array}$ & $\begin{array}{l}\text { Mean progeny } \\
(5 \text { weevils })^{\mathrm{a}}\end{array}$ & $\begin{array}{l}\text { Average MDT } \\
(\mathrm{d})^{\mathrm{a}}\end{array}$ & $\begin{array}{l}\text { Modified Dobie's } \\
\text { index }\end{array}$ & $\begin{array}{l}\text { Mean weight } \\
\text { loss }(\%)^{a}\end{array}$ \\
\hline $\begin{array}{c}0 \\
4 \\
8 \\
13\end{array}$ & $\begin{array}{l}263 \pm 24 a^{\ddagger} \\
263 \pm 22 a \\
270 \pm 56 a \\
267 \pm 7 a\end{array}$ & $\begin{array}{l}44.2 \pm 0.4 a \\
42.7 \pm 0.5 b \\
43.1 \pm 0.15 b \\
42.9 \pm 0.6 b\end{array}$ & $\begin{array}{l}12.6 \pm 0.2 \mathrm{a} \\
13.0 \pm 0.3 \mathrm{a} \\
13.0 \pm 0.6 \mathrm{a} \\
13.0 \pm 0.2 \mathrm{a}\end{array}$ & $\begin{array}{l}3.4 \pm 0.4 \mathrm{a} \\
3.1 \pm 0.7 \mathrm{a} \\
2.8 \pm 0.4 \mathrm{a} \\
3.1 \pm 0.4 \mathrm{a}\end{array}$ \\
\hline $\begin{array}{c}r \\
P \\
\text { slope } \\
\text { intercept }\end{array}$ & $\begin{array}{c}0.07 \\
0.76 \\
\mathrm{nc} \\
\mathrm{nc}\end{array}$ & $\begin{array}{l}0.54 \\
0.013 \\
-0.08 \\
43.7\end{array}$ & $\begin{array}{l}0.36 \\
0.12 \\
0.028 \\
12.8\end{array}$ & $\begin{aligned} & 0.29 \\
& 0.21 \\
&- 0.03 \\
& 3.3\end{aligned}$ \\
\hline $\begin{array}{l}\text { a Mean } \pm \text { Stan } \\
\ddagger \text { Means in the } \\
(P \leq 0.05) \text { ac } \\
\text { nc Not calculate }\end{array}$ & $\begin{array}{l}\text { deviation. } \\
\text { me column follo } \\
\text { ling to Newman }\end{array}$ & $\begin{array}{l}\text { d by the same } \\
\text { uls test. }\end{array}$ & tter are not sig & antly different \\
\hline
\end{tabular}


with bug attack level. However, the lowest value of the susceptibility index was observed with sound grain, while it was higher but unvariable for all other levels of incorporation of bug-damaged wheat as previously observed with MDT. The mean weight loss per kernel, caused by the development of internal stages of the rice weevil in the kernel did not change (Table 4). A weevil larva inside a kernel should eat about the same quantity of endosperm to complete its development, whether the kernel is bug-damaged or not.

\section{Correlations between technological parameters and biological performances of rice weevils}

Percent bug-damaged kernels was correlated with an increase in ash content and in level of damage for breadmaking capacity (virulence) (Table 5) as it was in previous analysis on freshly harvested grain batch (Table 2). Other parameters such as degradable nitrogen, falling number and mean developmental time, were not significantly correlated with percent bug-damaged kernels using pair-wise analysis (Table 5), although they were using other methods of analysis (Tables 2, 4). Degradable nitrogen was inversely correlated with nitrogen content (Table 5) but positively with the number of $S$. oryzae progeny produced. This link existing between the decrease in nitrogen content and the percent degradable ritrogen is reasonable as higher the level of bug damage and the withdrawal of digested endosperm by the wheat bug, lower the protein content remaining in the kernel. In addition, enzymes remaining in the grain endosperm after bug attack probably increased the percentage of degradable nitrogen, improving protein assimilation by $S$. oryzae larvae, inducing a slightly shorter MDT (Table 4). As to be expected, there was an inverse correlation between falling number and virulence. When the bug damage increases, both the bread-making capacity (assessed through the virulence index increase) and the falling number index decreased. This had been also shown in a previous work where W

Table 5. Correlation coefficients matrix showing pair-wise comparisons among the data characterizing the biological response of the rice weevil and the physico-chemical and rheological properties of wheat damaged by the wheat bug at different levels

\begin{tabular}{|c|c|c|c|c|c|c|c|c|c|}
\hline Variables $^{a}$ & Virulence & $\begin{array}{l}\text { Falling } \\
\text { number }\end{array}$ & Ash & $\begin{array}{c}\text { Degradable } \\
\text { nitrogen }\end{array}$ & $\begin{array}{l}\text { Moisture } \\
\text { content }^{b}\end{array}$ & $\begin{array}{l}\text { Progeny } 5 \\
\text { females }\end{array}$ & $\underset{\text { content }}{\mathrm{N}}$ & $\begin{array}{l}\% \text { damaged } \\
\text { kernels }\end{array}$ & MDT \\
\hline Virulence & 1 & & & & & & & & \\
\hline $\begin{array}{l}\text { Falling } \\
\text { number }\end{array}$ & $-0.92^{c}$ & 1 & & & & & & & \\
\hline Ash & 0.8 & -0.54 & 1 & & & & & & \\
\hline $\begin{array}{l}\text { Degradable } \\
\text { nitrogen }\end{array}$ & 0.82 & -0.77 & 0.81 & 1 & & & & & \\
\hline $\begin{array}{l}\text { Moisture } \\
\text { content }\end{array}$ & 0.05 & -0.35 & -0.55 & -0.29 & 1 & & & & \\
\hline $\begin{array}{l}\text { Progeny } 5 \\
\text { females }\end{array}$ & 0.76 & -0.81 & 0.63 & $0.96 *$ & -0.1 & 1 & & & \\
\hline $\mathrm{N}$ content & -0.65 & 0.54 & -0.82 & $-0.95^{*}$ & 0.55 & -0.88 & 1 & & \\
\hline $\begin{array}{l}\% \text { damaged } \\
\text { kernels }\end{array}$ & $\underline{0.92}$ & -0.73 & $0.97^{*}$ & 0.88 & -0.34 & 0.74 & -0.82 & 1 & \\
\hline MDT & -0.85 & 0.79 & -0.53 & -0.41 & -0.37 & -0.34 & 0.17 & -0.66 & 1 \\
\hline
\end{tabular}

* Error level of inter-variable correlation coefficient $\leq 0.05$ ( $t$-test).

Equilibrated statistical design with four data per variable.

b Percentage on wet basis.

c Underlined coefficient if marginal significance : $0.05 \leq P \leq 0.1$. 
and falling number had been measured on a very high quality wheat cultivar mixed with different levels of bug-damaged kernels (Menadi 1989).

A principal component analysis was performed in order to show the main interactions in the changes caused by the progressive degradation of wheat kernel quality through bug damage (Table 6 and Fig. 2). Seven variables of physico-chemical, technological, or rheological properties as explanatory variables and two biological variables describing $S$. oryzae biological response were used for the PCA (Table 6). Principal component axis 1 describes grain quality (Fig. 2). High quality grain is associated with high nitrogen content, high falling number, low ash content, low virulence index, low \% degradable nitrogen, longer developmental time for $S$. oryzae and fewer progeny. Percent bug-damaged grain points, co-ordinated on principal components correlation circle, are arranged in decreasing magnitude along the principal component axis 1 . The second axis only described the variation caused by the moisture content and the weight loss induced by $S$. oryzae development. It was not consistent along damage levels which gradient was moving clockwise in the plan delimited by the two first principal components. The importance of this clear-cut segregation of the four levels of bug damage on principal components correlation circle should not be minimised. This result indicated that the consequences of the bug damage increase for technological properties of wheat flour and for biological response of $S$. oryzae are probably more exactly related to the complex relationship existing between the measured variables than to the set of significant pairwise correlations. Progeny per female weevil should be more important in 8 and $13 \%$ level of damaged kernels, these highest levels of bug damage being associated with a higher mineral ash content. The importance of cellulosic outer layers of the kernel as an oviposition enhancing factor has been demonstrated before for the rice weevil on brown rice kernels (Haryadi and Fleurat-Lessard 1994). The weight loss induced by a generation of weevils was inversely related to moisture content, as expected. Higher the moisture content of the kernel, easier the female weevil can bore a hole for egg laying and can the larva borrow its run. In addition, kernels with the highest level of bug attack had a lower moisture content, as if the bug damage to the kernel had allowed the kernel to dry more completely after the bug puncture and before complete dryness of kernel occurred before the harvest.

We have shown that the attack of immature grain by wheat bug in the field before harvest has severe conse-

Table 6. Principal components (PC) correlation matrix showing the relative importance of the variables on each principal component, the co-ordinates of the variables on PC1 and PC2 axes and the percentage of variability accounted for by each principal component

\begin{tabular}{|c|c|c|c|c|c|}
\hline \multirow[b]{2}{*}{ Analytical variables } & \multirow[t]{2}{*}{$\begin{array}{c}\text { Principal } \\
\text { component } 1 \\
\text { (PC1) }\end{array}$} & \multirow[t]{2}{*}{$\begin{array}{c}\text { Principal } \\
\text { component } 2 \\
\text { (PC2) }\end{array}$} & \multirow[t]{2}{*}{$\begin{array}{c}\text { Principal } \\
\text { component } 3 \\
\text { (PC3) }\end{array}$} & \multicolumn{2}{|c|}{$\begin{array}{l}\text { Co-ordinates of } \\
\text { variables in PC1-PC2 } \\
\text { delimited plan }\end{array}$} \\
\hline & & & & PC1 & $\mathrm{PC} 2$ \\
\hline Moisture content & 0.179 & -0.98 & 0.086 & 0.176 & -0.981 \\
\hline Mineral ash & -0.875 & 0.405 & 0.265 & -0.875 & 0.405 \\
\hline Nitrogen content & 0.912 & -0.267 & 0.31 & 0.911 & -0.269 \\
\hline Degradable nitrogen & -0.984 & 0.002 & -0.177 & -0.984 & 0.004 \\
\hline Loss in weight & 0.418 & 0.891 & 0.174 & 0.421 & 0.89 \\
\hline Falling number & 0.812 & 0.554 & -0.185 & 0.813 & 0.552 \\
\hline Virulence index & -0.985 & 0.048 & 0.166 & -0.984 & 0.051 \\
\hline \multicolumn{6}{|l|}{ Biological variables } \\
\hline Progeny of 5 females $S$. oryzae & -0.92 & -0.22 & -0.33 & -0.922 & 0.214 \\
\hline Median Developmental Time & 0.75 & 0.31 & -0.58 & 0.751 & 0.305 \\
\hline Contribution to the variation & $62.9 \%$ & $32.9 \%$ & $4.2 \%$ & & \\
\hline
\end{tabular}




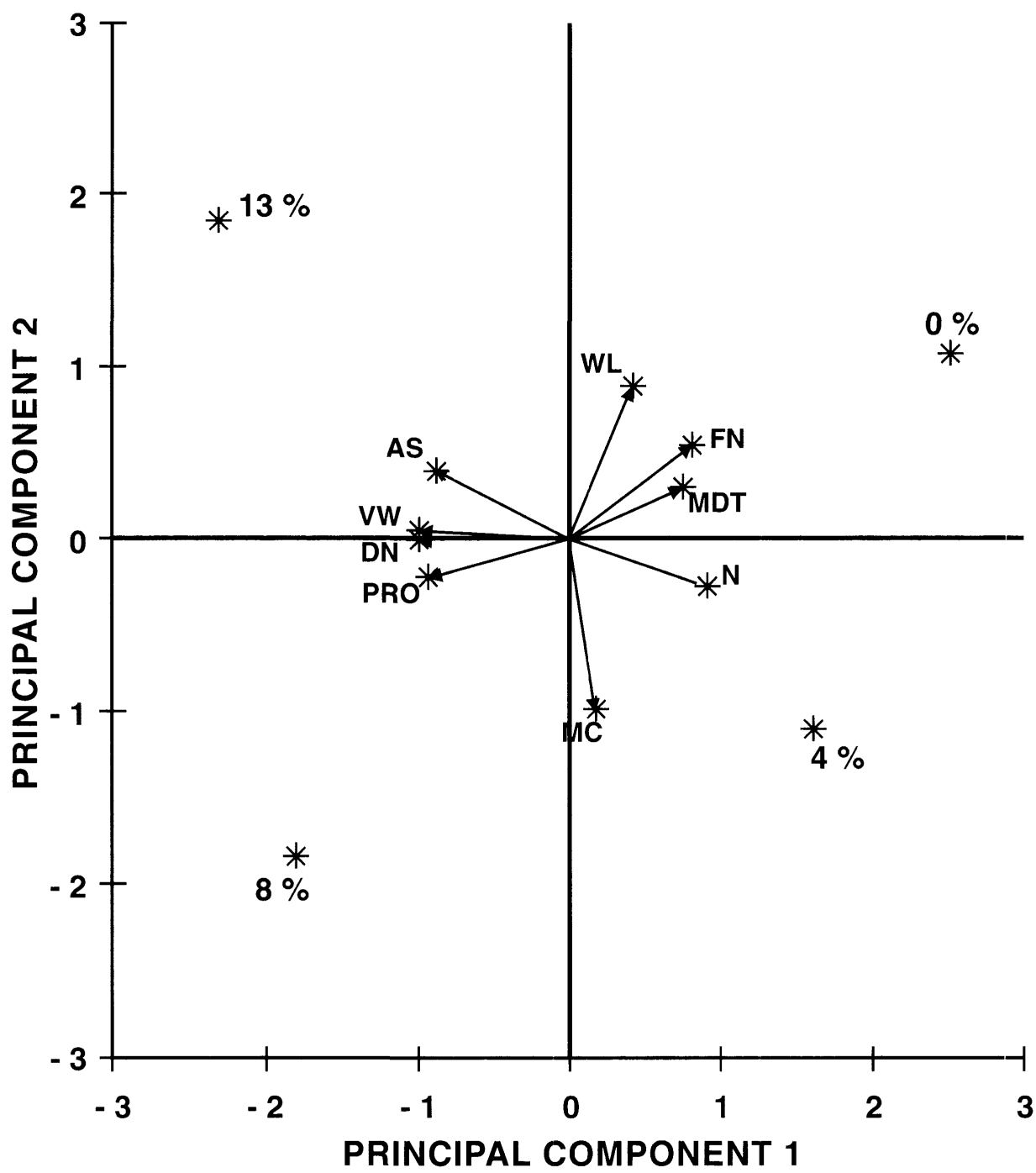

Figure 2. Correlation circle in PCA showing the linkage of the different levels of bug damage in wheat with technological parameters and biological characteristics of $S$. oryzae las follows) :

Technological parameters:

$\mathrm{MC}=$ moisture content; $\mathrm{AS}=$ ash (mineral); $\mathrm{N}=$ nitrogen; $\mathrm{DN}=$ degradable nitrogen;

$\mathrm{WL}=$ weight loss; $\mathrm{FN}=$ falling number; $\mathrm{VW}=$ "virulence" on baking strength (W).

Biological characteristics (of weevils) :

MDT = median developmental time; $\mathrm{PRO}=$ progeny per female.

Level of bug damage:

$0 \%=$ sound grain; $4 \%=4 \%$ bug-damaged; $8 \%=8 \%$ bug-damaged; $13 \%=13 \%$ bugdamaged. 
quences on rheological properties of bread-making dough at $4 \%$ damaged kernels, at a level lower than previously described (Gaffour-Bensebbane 1979; Menadi 1989; Swallow and Every 1991), and observed here as low as $4 \%$. In addition, we assume that residual activity of enzymes remaining in harvested grain after bug damage is the prime cause of prevention of use for bread making of flour coming from wheat with more than $8 \%$ wheat-bug-damaged kernels. This threshold is far less than commercial tolerance in countries where wheat bugs are common pests, (e.g., threshold is fixed at $13 \%$ bugdamaged kernels in Algeria). The reduction in developmental time of $S$. oryzae could be due to a better assimilation of gluten and starch in grain endosperm during larval growth. The biological response of the weevil to nutritional quality changes in grain is detectable at low damage levels and it could be used as an indirect measure for protein and starch nutritive value alteration in bread making wheat. Nevertheless, this bioassay is too lengthy and a better approach would be an ELISA test with specific antibodies for the proteases remaining within bugdamaged kernels. This kind of test is already used for the detection of traces of insect muscle myosin within cereal grain or flours (Kitto 1991).

Although interactions among the wheat bug feeding during the growth of wheat and the quality characteristics of the harvested grain have been clearly demonstrated here, some other factors may affect wheat quality. Further studies are needed to determine the importance of factors such as the delay of time from the bug feeding to the grain maturity stage, the different pentatomids species involved in wheat crop attack, and the susceptibility of different wheat cultivars to bug attack.

\section{AKNOWLEDGEMENTS}

The authors are grateful to ENIAL Blida (Algeria) for comprehensive support of the researcher who did the major part of this study. We are also grateful to the ENSMIC Laboratory in Paris (Mrs. C. Mazerand) and to the INRA Laboratory for plant analysis (Mr. G. Theiller) for their assistance in biochemical analysis of grain characteristics.

\section{REFERENCES}

Adams, J. M., and G.G.M. Schulten. 1978. Losses caused by insects, mites and microorganisms. Pages 83-95 in K.L. Harris and C.J. Lindblad (eds.), Post-harvest grain loss assessment methods. Am. Assoc. Cereal Chem., St. Paul, MN, USA.

Aufrere, J., and B. Michalet-Doreau. 1988. Comparison of methods for predicting digestibility of feeds. Anim. Feed Sci. Technol. $20: 203-218$.

Bekon, K.A., and F. Fleurat-Lessard. 1988. Influence de la variation de la teneur en eau des farines de blé et de maïs sur la descendance et la durée de développement de Tribolium castaneum (Herbst.) (Coleoptera : Tenebrionidae). Ann. Univ. Abidjan, XXII B : 273-285.

Davis, G.R.F., and F.W. Sosulski. 1976. Nutritional evaluation of wheat and barley cultivars by growth rate and body composition of larvae of Tenebrio molitor. Arch. Int. Physiol. Biochim. 84 : 235-246.

Dobie, P. 1974. The laboratory assessment of the inherent susceptibility of maize varieties to post-harvest infestation by Sitophilus zeamais Motsch. (Coleoptera: Curculionidae). J. Stored Prod. Res. 10 : 183-197.

Dubois, M., and M. Validzic. 1952. L'apport d'un complexe enzymatique dans les grains "punaisés". Enzymes agissant sur les matériaux hydrocarbonés. Bull. École Française Meunerie 132 : 214-218.

Gaffour-Bensebbane, C. 1979. Les punaises des blés en Algérie. Proc. Symp. Eur. Plant Prot. Organisation, Istambul, Turkey. EPPO, Paris.

Haryadi, Y. 1991. Sensibilité variétale du riz aux attaques de Sitophilus oryzae (L.) et de Sitotroga cerealella (Oliv.). Analyse de l'origine d'une résistance potentielle. Ph.D. thesis in Agronomical Sciences, Ecole Nat. Sup. Agronomie, Montpellier, France. $113 \mathrm{pp}$.

Haryadi, Y., and F. Fleurat-Lessard. 1994. Factors affecting survival and development of Sitophilus oryzae (L.) in rice grain pericarp layers. Pages 525-527 in E. Highley, E.J. Wright, H.J. Banks, and B.R. Champ (eds.), Stored product protection. $\mathrm{CAB}$ International, Wallingford, England. 
Hinton, J.J.C. 1959. The distribution of ash in the wheat kernel. Cereal Chem. $36: 19$ 21.

I. S. T. A. 1976. International rules for seed testing. Seed Sci. Technol. 4 : 609-743.

I. T. C. F. 1988. Stat-Itcf version 5 : logiciel de statistiques. ITCF, Paris, France.

Kitto, B. 1991. A new rapid biochemical technique for quantitating insect infestation in grain. Bull. Assoc. Operative Millers, March 1991 : 5835-5838.

Kosmin, N. 1933. Contribution to the knowledge of slimy gluten wheats. Muehlen Laboratorium 3 : 185.

Leclercq, J., and D. de Bast. 1965. Projet d'utilisation des larves de Tenebrio molitor pour comparer la valeur nutritive des protéines. Ann. Nutr. Aliment. 19 : 19-25.

Loschiavo, S. R., A.J. McGinnis, and D.R. Metcalfe. 1969. Nutritive value of barley varieties assessed with the confused flour beetle. Nature (London) 224 : 288.
Menadi, N. 1989. Contribution à la mise en évidence de l'incidence des farines issues des blés punaisés et essais $\mathrm{d}$ 'amélioration. Thèse Ingénieur Inst. Nat. Indus. Aliment. Blida, Algérie. 92 pp.

Mzali, H. 1977. Contribution à l'étude de la composition biochimique et des caractéristiques technologiques des blés tendres punaisés. Thèse doctorat: Inst. Nat. Agro. El Harrach, Algérie. 59 pp.

Svvallow, W.H., and D. Every. 1991. Insect enzyme damage to wheat. Cereal Foods World 36 : 505-508.

Zoubovsky, P. 1955. Essais pour la recherche de palliatifs en vue de l'amélioration des farines punaisées. Bull. École Française Meunerie 146 : 61-73. 